\title{
A corporate response to AIDS
}

\section{Private-sector employers who face up to the HIV epidemic in Africa must be encouraged, not harangued.}

— fforts to combat the AIDS pandemic in Africa and elsewhere are essentially public activities, led by national governments. Unfortunately, in many areas of Africa where the pandemic is most serious, the governments are barely functional. In some regions, there is no real authority in existence to help implement the monitoring, prevention and treatment of AIDS. In others, the body best placed to tackle the problem of AIDS may be the oil company, brewer or mining company whose presence dominates the local economy.

In this issue, Nature examines efforts being initiated by the oil and gas industryin one of Africa's most politically febrile and strategically important regions - the Niger River delta — to build a communitybased programme that will limit the spread of AIDS (see page 140). This project is difficult to implement and fraught with risk. Yet it is an important experiment and, if successful, it could provide one way of tackling an immensely exacting challenge.

The Ibani-se initiative on Bonny Island, at the mouth of the Niger River, is being supported primarily by Nigeria Liquefied Natural Gas (NLNG), a joint venture between the Nigerian government and the energy companies Shell, ENI and Total. NLNG's main plant employs some 17,000 people and, at a cost of US $\$ 15$ billion so far, is thought to be the largest single fixed investment in Africa.

The scheme is intended to engage every element of the island's community, from sex workers to truck drivers and shopkeepers, in building a programme that will study the pandemic in detail while undertaking educational and self-help programmes to limit its spread. As the programme develops, it will make antiretroviral drug treatment available, free of charge, to those who need it.

One of the many tragedies of AIDS in Africa is its propensity to strike at the most economically active members of the population. Major hubs of activity such as the NLNG plant are particularly vulnerable to the ravages of the epidemic. Yet given the size of the population just outside the plant - tens of thousands of migrants have been drawn to Bonny Island alone - it is unrealistic to expect the plant's operators to support AIDS prevention and treatment programmes for the general population.

The best outcome, instead, is for companies such as NLNG to use their extensive logistical abilities to help forge a community-based initiative that will eventually attract sustainable funding from outside sources, such as the Global Fund to Fight AIDS, Tuberculosis and Malaria, or the US President's Emergency Plan for AIDS Relief. That will require a project that is strongly identified with the private sector to forge an effective partnership with the public sector. This sounds simple but, as in many parts of Africa, it is in fact immensely difficult. Government officials at the local and national level have their own priorities and tend to assume that projects backed by corporations can look after themselves. The corporations, meanwhile, have learned to expect little in the way of competence or probity from public officials.

The multinational corporations have plenty to lose by squaring up publicly to the problem. Talk of the need for transparency and openness is cheap, but what employer really wants the painful facts about the extent of an AIDS epidemic among its employees to enter the scientific literature, or anywhere else in the public domain? At long last, major employers, such as multinational mining conglomerate Anglo American and NLNG, are biting the bullet in this regard and should be commended for doing so.

Private-public collaboration in tackling AIDS remains at an early stage of development, however. Some major companies still decline to participate, and the national committees that coordinate Global Fund programmes often remain unresponsive. The Global Fund won't tell these committees what to do - but it should prod them firmly in the direction of partnership with the private sector. Corporations, which are often the most viable institutions in their vicinities, have to accept some level of responsibility for what goes on there. But the penny has to drop that these companies, profitable as they may be, are not going fund health provision beyond that for their employees and immediate families.

In the West there is a widespread tendency to assume that the activities of multinationals in Africa are entirely malign. Some observers of political disquiet in Nigeria seem to think it would be better if Shell, for example, just packed its bags and went home. That is simply ridiculous. With AIDS, as in other spheres of social policy, the multinationals are not the problem. They should instead be seen as part of the solution.

\section{Off the rails}

\section{Aviation's role in climate change is causing a storm.}

W hen a politician is accused of being "foolish", "ill-informed" and not having "a clue what he's talking about", you might expect the complaints to be legitimate. But such venomous language could also betray a different explanation: the politician may have rattled someone's cage. So it was last week, when aviation boss
Michael O'Leary reacted furiously to comments made by Ian Pearson, the British government's hitherto low-key environment minister.

Pearson had accused Ryanair, the Irish budget airline that O'Leary runs, of doing too little to tackle climate change, memorably branding the airline "the irresponsible face of capitalism". The fact that O'Leary protested rather too much was down to more than his well-earned reputation as a self-publicist. As pressure grows on the aviation industry, Ryanair and other airlines find themselves in an increasingly uncomfortable position.

The problem lies with two diverging industry trends. On the one 
hand, flying is more popular than ever before. British passenger numbers are predicted to double to 475 million per year by 2030, for example, and in China, according to the World Bank, passenger numbers grew by a whopping $28 \%$ from 2003 to 2004 .

Progress in improving the fuel efficiency of aircraft is, by contrast, gradual. Current trends suggest that gains of $1-2 \%$ per year will be the norm for the foreseeable future. Only a step change in aeroengine design might increase this, but with current approaches being so safe and reliable, and change so expensive, that seems improbable.

As a result, the growth in aviation emissions, if left unchecked, is liable to wreck attempts to reduce greenhouse-gas emissions. In Britain, for example, airlines' emissions are growing by around $7 \%$ each year, even as the government prepares to set in law a commitment to cut national emissions to $60 \%$ below 1990 levels by 2050 . According to the Tyndall Centre for Climate Change Research, the rest of the economy would have to move to zero emissions in order to sustain aviation growth and meet the target.

It is clear that something will have to give. If real cuts are to be made in carbon emissions, aviation growth will certainly have to level off. The number of trips may even need to be cut. These are truths that the airline industry does not want to hear.

The first moves towards such a future are now being made. The European Commission announced in December that it plans to include domestic flights in its carbon emissions trading scheme by 2011, with intercontinental flights joining the scheme the following year. This is a critical first step towards a future in which consumers start to pay for the environmental cost of flying.

For now, several European airlines say they are in favour of emissions trading, perhaps because they anticipate being eased gently into the scheme with relatively generous emissions targets. The full test of their support will come in the years after the scheme starts, when emissions will need to be capped tightly enough to reduce the growth in airline traffic.

But some, led by O'Leary's Ryanair, are opposed from the start. US airlines are sending an equally indignant message behind the scenes, Pearson says. This opposition may lead to a legal challenge from US airlines to the proposed inclusion of intercontinental flights.

European Commission officials say they are confident of the legality of their approach. But if the US legal action or non-cooperation of the airlines make emissions trading unworkable, more radical alternatives may have to be considered. One such approach would be to review European adherence to the 1947 Chicago Convention, the international agreement that prohibits the taxation of aviation fuel, and hence gives the industry a permanent advantage over its competition, such as rail travel. That would really give O'Leary and his allies something to squeal about.

\section{Competitive stumbling}

\section{Promised investment in the physical sciences is held up in a US budget jam.}

n his State of the Union Address last January, President George W. Bush announced an American Competitiveness Initiative, which included substantial increases in funding for the physical sciences as a means of securing US industrial competitiveness in the long term. This laudable initiative set out to increase expenditure on research in physics, engineering and other disciplines at the National Science Foundation, the Department of Energy and the National Institute of Standards and Technology.

Leading Republicans and Democrats have expressed strong support for such a step, and as the president's proposal moved through the congressional budget process last year, all three agencies were looking forward to significant growth during 2007.

But despite the goodwill, an unusual turn in the budget saga has caused the gains to vanish overnight. The outgoing Republican Congress never finished the 2007 budget, as it should have done by 1 October 2006. That left the incoming, Democrat-controlled one to decide what to do with the unfinished appropriations bills. But the Democrats want to focus on the issues that they think got them elected, such as lobbying reform and the war in Iraq. Instead of completing last year's spending bills, the Democrat chairs of the appropriations committees have said they plan to stick with 2006 funding levels through the whole of the 2007 fiscal year (see page 130).

The announcements left lab directors and agency administrators who stood to benefit from the competitiveness initiative protesting about sharp cutbacks in extramural grants and sidelined intramural facilities. Some of this is exaggerated, but there is no denying that the physical sciences will suffer as a result of this turn of events. Because the House and Senate had already approved the increases, agencies were incorporating them into budget planning. Tough choices must now be made at the last minute to ensure that the agencies can operate until 30 September, when the fiscal year ends. In other words, the sudden retraction of the increases is more damaging than if they had never been mooted in the first place.

The bill to keep spending at 2006 levels will probably be finalized and passed in the next few weeks, and science lobbyists in Washington are scrambling to have an exception made for the competitiveness initiative. They have a strong case, and given the bipartisan support for the initiative's main elements, they deserve to succeed. Unfortunately, it is more likely that appropriators will make exceptions only for a few politically sensitive agencies, such as the Department of Veterans' Affairs.

All eyes will then turn to the presi-
"The sudden retraction of the funding increases is more damaging than if they had never been mooted in the first place." dent's budget proposal for 2008, to be released on 5 February. Despite the president's well-known political difficulties, his proposal will set the tone for the subsequent budget process. Science advocates have been pressing hard to ensure that Bush's proposal makes up for this year's shortfalls. And scientists should urge their own congressional representatives to ensure that the 2008 budget reflects both the withdrawn increase for 2007 and that originally envisaged for 2008 . With the right support, it may still be possible to get the American Competitiveness Initiative back on track. 